\title{
PENGARUH JARAK TANAM DAN INTERVAL PENYEMPROTAN EKSTRAK DAUN Muntingia calabura TERHADAP HAMA Spodoptera litura, F PADA BUNGA KOL (Brassica oleracea, L)
}

\author{
Cut Mulyani $^{1}$, Maria Heviyanti ${ }^{1}$, Ichan Hardiansyah ${ }^{2}$ \\ ${ }^{1}$ Dosen rogram Studi Agroteknologi, Fakultas Pertanian Universitas Samudra \\ ${ }^{2}$ Alumni Program Studi Agroteknologi, Fakultas Pertanian Universitas Samudra \\ e-mail: Cutmulyani@gmail.com
}

\begin{abstract}
ABSTRAK
Penelitian ini bertujuan untuk mengetahui pengaruh jarak tanam bunga kol Brassica oleracea, L dan interval penyemprotan ekstrak daun Muntingia calabura terhadap hama Spodoptera litura, F pada tanaman bunga kol. Penelitian ini dilaksanakan di Desa Paya Bujok Braumoe, Kecamatan Langsa Barat, Kota Langsa, Penelitian ini dimulai pada Bulan Januari hingga Maret 2019. Penelitian ini menggunakan Rancangan Acak Kelompok (RAK) pola faktorial, yang terdiri dari 2 faktor yaitu; faktor interval penyemprotan (I) yang terdiri dari 3 taraf, yaitu $\mathrm{I}_{1}=4 \mathrm{MST}, \mathrm{I}_{2}=6 \mathrm{MST}$ dan $\mathrm{I}_{3}=8 \mathrm{MST}$. Faktor kedua jarak tanam (J) $\mathrm{J}_{1=} 40 \mathrm{x} 40$ $\mathrm{cm}, J_{2}=50 \times 50 \mathrm{~cm}$, dan $J_{3=} 60 \times 60 \mathrm{~cm}$. Parameter yang diamati dalam penelitian ini yaitu tinggi tanaman,lingkaran krop bunga kol, bobot krop dan intensitas serangan. Hasil penelitian menunjukan interval penyemprotan ekstrak daun kersen berpengaruh sangat nyata terhadap tinggi tanaman umur 14, 21, dan 28 HST dan bobot krpo, berpengaruh nyata terhadap lingkaran krop. Jenis interval penyemprotan terbaik dijumpai pada perlakuan $\mathrm{I}_{3}(8 \mathrm{MST})$. Jarak tanam bunga kol berpengaruh sangat nyata terhadap tinggi tanaman umur 14 HST, bobot krop, dan berpengaruh nyata pada tinggi tanaman umur 21 dan 28 HST, diameter krop. Jarak tanam terbaik dijumpai pada perlakuan $\mathrm{J}_{3}(60 \mathrm{x} 60)$. Interaksi interval penyemprotan dan pengaruh jarak tanam berpengaruh sangat nyata pada pengamatan tinggi tanaman umur 14 HST, tetapi berpengaruh tidak nyata terhadap semua parameter lainnya. Kombinasi perlakuan terbaik dijumpai pada perlakuan $\mathrm{I}_{3} \mathrm{~J}_{3}(8 \mathrm{MST}$ dan $60 \times 60 \mathrm{~cm})$. Berdasarkan hasil penelitian ini, untuk mengendalikan hama ulat (Spodoptera litura, F) pada tanaman bunga kol disarankan menggunakan interval penyemprotan ekstrak daun kersen dengan penyemprotan tiga kali penyemprotan dalam satu minggu dan menggunakan jarak tanam 60 x $60 \mathrm{~cm}$ untuk mendapatkan pertumbuhan dan hasil yang optimal.
\end{abstract}

Kata kunci : Bunga kol, Muntingia calabura, hama, jarak tanam.

\section{PENDAHULUAN}

$\begin{array}{lrr} & \text { Pengaturan jarak } & \text { tanam } \\ \text { sangat berpengaruh } & \text { terhadap } \\ \text { pertumbuhan dan hasil tanaman } & \text { tanan } \\ \text { kubis terutama pada } & \text { masa }\end{array}$

pembentukan krop, yaitu sangat bervariasi antara bulat telur, gepeng, dan bentuk kerucut. Dengan demikian jarak tanam ditunjukan untuk memanfaatkan cahaya secara efektif dan penyebaran insektisida 
botani diharapkan dapat menjadi salah satu alternatif pengendalian yang sesuai dengan konsep Pengendalian Hama Terpadu (PHT) karena sifatnya mudah terurai dialam dan umumnya relatif aman terhadap musuh alami. Meskipun tidak dapat menekan populasi hama sampai pada tingkat merugikan, insektisida nabati cukup aman terhadap musuh alami.

Masalah yang dihadapi oleh petani pada saat ini yaitu penurunan produksi kubis yang dihasilkan salah satunya disebabkan oleh adanya serangan hama, penyakit, serta tumbuhan pengganggu. Kerugian besar bahkan kegagalan panen dapat terjadi bila gangguan tersebut tidak diatasi dengan baik. Kehilangan hasil kubis akibat serangan hama cukup tinggi. Oleh karena itu perlu adanya penangan untuk mengatasi serangan hama pada tanaman kubis, salah satu hama pada tanaman budidaya tanaman kubis yaitu ulat grayak (Spodoptera litura, F). Kegagalan panen yang disebabkan oleh serangan hama ulat grayak dapat mencapai $85 \%$. Hama ini memiliki sifat polifag sehingga ia dapat memakan berbagai jenis tanaman demi kelangsungan hidupnya (Widodo, 2013).

Berbagai cara digunakan untuk melakukan pengendalian untuk mengatasi hama ulat grayak pada tanaman kubis, seperti menggunakan varietas tahan hama, pergiliran tanaman hingga menggunakan pestisida. Penggunaan pestisida kimia dapat mengendalikan serangan hama ulat grayak, akan tetapi penggunaan pestisida kimia yang terus-menerus dapat menimbulkan masalah lainnya seperti resistensi hama, terjadinya residu pada tanah, terbunuhnya musuh alami dan dapat mencemari

lingkungan

(Untung, 2013).

Penggunaan pestisida nabati dapat menekan penggunaan pestisida kimia, juga penggunaan pestisida nabati ramah lingkungan. Salah satunya dalam pengendalian hama ulat grayak pada tanaman kubis dapat menggunakan pestida nabati salah satunya dari ekstrak daun kersen (Muntingia calabura). Dengan menggunakan ekstrak daun kersen hasil penelitian menunjukkan bahwa ekstrak daun kersen dapat menurunkan tingkat populasi hama sebanyak $25 \%$ - $50 \%$ yang dicampurkan dengan air dan larutan etanol dengan konsentrasi tertentu, karena di dalam ekstrak daun kersen terdapat senyawa flavonoid, saponin, triterpene dan steroid (Zakaria $d k k$, 2007). Penelitian ini bertujuan untuk mengetahui pengaruh jarak tanam dan interval penyemprotan ekstrak daun Muntingia calabura terhadap hama Spodoptera litura $\mathrm{F}$ pada bunga kol (Brassica oleracea L).

\section{METODE PENELITIAN}

Penelitian ini dilaksanakan di Desa Paya Bujok Beuraumoe Kecamatan Langsa Barat Kota Langsa. Penelitian ini dimulai pada bulan Januari hingga Maret 2019.

Bahan-bahan

yang digunakan: benih bunga kol Varietas Aquina F1 Cap Panah merah yang diproduksi oleh PT East West Seed Indonesia, daun kersen yang masih segar, tanah pasir, pupuk kandang, pupuk Urea, pupuk KCL, pupuk SP36, dan Fungisida dari ekstrak bawang putih.

Alat-alat yang digunakan: meteran, kamera, gembor, gunting, pisau, parang, cangkul, babat, alat 
tulis, timbagan analitik dan paranet, atap, babybag alat-alat lain yang menunjang penelitian ini.

Penelitian ini menggunakan Rancangan Acak Kelompok (RAK) pola faktorial yang terdiri dari: Faktor interval penyemprotan (I) terdiri dari 3 taraf yaitu: $\mathrm{I}_{1}=4 \mathrm{MST}$, $\mathrm{I}_{2}=6 \mathrm{MST}$ dan $\mathrm{I}_{3}=8 \mathrm{MST}$; Faktor jarak tanam $(\mathrm{J})$ yang terdiri dari : $\mathrm{J}_{1}=$ $40 \times 40 \mathrm{~cm}, \mathrm{~J}_{2}=50 \times 50 \mathrm{~cm}$ dan $\mathrm{J}_{3}=$ $60 \times 60 \mathrm{~cm}$. Dari 2 faktor diatas diperoleh 9 kombinasi perlakuan, setiap perlakuan diulang sebanyak 3 kali, sehingga terdapat 27 satuan percobaan. Setiap satuan percobaan terdiri dari 4 tanaman Sehingga secara keseluruhan tanaman yang digunakan dalam penelitian ini adalah 144 tanaman yang tediri dari (1 benih/ lubang tanam) dan jumlah tanaman sampel dalam plot yaitu sebanyak 4 tanaman/plot.

Model matematika yang digunakan dalam penelitian ini (Hanafiah, 2010).

$\mathbf{Y}_{\mathbf{i j k}}=\boldsymbol{\mu}+\boldsymbol{\beta}_{\mathbf{i}}+\mathbf{I}_{\mathbf{J}}+\mathbf{J}_{\mathbf{k}}+\boldsymbol{€} . \quad$ Data dianalisis dengan uji $F$ (Sidik
Ragam), tehadap hasil analisis sidik ragam yang berpengaruh nyata dan sangat nyata di lanjutkan dengan uji beda nyata terkecil (BNT) taraf 5\%. Parameter yang di amati: tinggi tanaman $(\mathrm{cm})$, lingaran krop bunga kol (cm), bobot krop (gr) dan intensitas serangan hama.

\section{HASIL DAN PEMBAHASAN}

Pengaruh Jarak tanam pada Tanaman Bunga Kol terhadap Hama (Spodoptera litura, F)

\section{Tinggi Tanaman}

Analisis sidik ragam menunjukkan bahwa perlakuan faktor jarak tanam berpengaruh sangat nyata terhadap tinggi tanamanbunga kol umur 14 HST dan berpengaruh tidak nyata pada umur 21 dan 28 HST. Rata-rata tinggi tanaman bunga kol akibat pengaruhjarak tanam pada umur 14 , 21 dan 28 disajikan pada Tabel 1.

Tabel 1. Rata-rata tinggi tanaman bunga kol pada umur 14, 21 dan 28 HST (cm)

\begin{tabular}{cccc}
\hline \multirow{2}{*}{ Perlakuan } & \multicolumn{3}{c}{ Tinggi tanaman } \\
\cline { 2 - 4 } & $14 \mathrm{HST}$ & $21 \mathrm{HST}$ & $28 \mathrm{HST}$ \\
\hline $\mathrm{J}_{1}$ & $19,46 \mathrm{a}$ & 21,58 & 23,36 \\
$\mathrm{~J}_{2}$ & $20,98 \mathrm{~b}$ & 22,88 & 24,08 \\
$\mathrm{~J}_{3}$ & $21,61 \mathrm{c}$ & 23,26 & 29,22 \\
\hline BNT $_{0,05}$ & 0,22 & - & - \\
\hline
\end{tabular}

Keterangan : Angka yang diikuti pada huruf yang sama pada kolom yg sama berbeda tidak nyata pada uji BNT 0,05

Tabel 1 hasil uji BNT pada umur tanaman bunga kol 14 HST menunjukkan perlakuan $\mathbf{J}_{3}(60$ × 60 $\mathrm{cm})$ berbeda nyata dengan perlakuan $\mathrm{J}_{1}(40 \times 40 \mathrm{~cm})$ dan $\mathrm{J}_{2}(50 \times 50 \mathrm{~cm})$. Pada tabel 2 menunjukkan bahwa hasil terbaik tanaman kubis akibat faktor jarak tanam tertinggi ditemui pada perlakuan $\mathbf{J}_{3}(60 \mathrm{x} \quad 60 \mathrm{~cm})$ sedangkan terendah dijumpai pada perlakuan $\mathrm{J}_{1}(40 \times 40 \mathrm{~cm})$. Hal ini disebabkan karena adanya perebutan terhadap unsur hara. Semakin jauh 
jarak antara tanaman, maka semakin baik pertumbuhan tanaman kubis.

Pengaturan jarak tanam tersebuttidak hanya memberikan implikasi terhadap hasil persatuan luas, tetapi juga terhadap rata-rata ukuran bunga kol yang dihasilkan yangmenentukan nilai tambahan komoditas. Jarak tanam diusahakan teratur agar tanaman memperoleh ruang tumbuh yang seragam, dan dalam pemeliharaan lebih mudah serta mempermudah dalam melakukan penyiangan jarak tanam sangat berpengaruh terhadap pertumbuhan tanaman dan pembentukan krop. Pada Tabel 1 pengamatan tinggi tanaman 21 dan 28 HST menunjukkan hasil yang tidak nyata. Hal ini dikarenakan curah hujan yang tinggi, sehingga tanaman tidak dapat berkembang dengan baik. Pembentukan daun baru akan berakibat meningkatnya jumlah daun tanaman, sehingga hasil produksi tanaman juga meningkat.

\section{Prawitasari}

(2003),

menjelaskan bahwa perubahan pertumbuhan kearah perkembangan hasil tanaman dipengaruhi oleh kemampuan kerja enzim dalam tubuh tanaman dan faktor lingkungan. Pertumbuhan dan perkembangan organ ditentukan oleh suatu proses yang dinamakan fotosintesis bila hasilnya baik maka akan menghasilkan pertumbuhan dan perkembangan tanaman yang baik pula, hal ini dapat terukur pada penambahan jumlah organ tanaman, perluasan sel-sel dan proses fotosintesis dapat berjalan dengan baik bila faktor (hara, suhu dan udara) yang mempengaruhi proses tersebut berada pada kondisi optimum. Suhu mempunyai pengaruh kuat pada reaksi-reaksi biokimia dan fisiologi tanaman juga akan menentukan tingkat berbagai aktifitas tanaman, seperti penyerapan unsur hara dan air (Setyati, 1983). Tanaman kubis dapat menyerap unsur hara dengan baik apabila suhu disekitarnya dalam kondisi optimum.

\section{Lingkaran Krop}

Analisis sidik ragam menunjukkan bahwa perlakuan faktor jarak tanam tidak berpengaruh nyata pada tanaman bunga kol. Hal ini diduga jarak tanam yang terlalurapat meningkatkan kelembapan disekitar tanaman, keadaan ini dapat memacu pertumbuhan dan perkembangan organisme pengganggu, selain itu juga berpengaruh pula terhadap penerimaan sinar matahari pada setiap tanaman sehingga dapat mempengaruhi pertumbuhan dan hasil tanaman kubis (Suprapto 1992). Rata-rata bobot lingkaran krop tanaman bunga kol akibat pengaruh jarak tanam pada disajikan pada Tabel 2.

Tabel 2 . Rata-rata lingkaran krop (cm)

\begin{tabular}{cc}
\hline Perlakuan & Lingkaran Krop \\
\hline $\mathbf{J}_{1}$ & 29,04 \\
$\mathrm{~J}_{2}$ & 42,99 \\
$\mathrm{~J}_{3}$ & 36,91 \\
\hline
\end{tabular}

\section{Bobot Krop}

Analisis menunjukkan bahwa perlakuan faktor jarak tanam berpengaruh nyata pada tanaman bunga kol. Rata-rata bobot krop tanaman kubis akibat 
pengaruh jarak tanam pada disajikan pada Tabel 3.

Hasil uji BNT pada Tabel 3 menunjukan bahwa rata rata bobot krop pada tanamanbunga kol tertinggi dijumpai pada perlakuan $\mathrm{J}_{1}$ berbeda nyata dengan perlakuan yang lain. Hal ini diduga jarak tanam $(60 \times 60 \mathrm{~cm})$ merupakan jarak tanam yang ideal untuk pertumbuhan krop pada tanaman kubis yang mana kebutuhan intensitas cahaya terpenuhi dengan baik untuk proses fotosintesis dan juga kebutuhan hara tanaman yang dapat diserap akan mencukupi untuk proses metabolisme tanaman, sehingga pada jarak tanaman $\mathrm{J}_{3}$ ini produksi hasil menunjukkan hasil yang tertinggi dan kurangnya terjadi persaingan unsur hara dalam perebutan makanan dalam proses pertumbuhan dan produksi tanaman.

Sesuai dengan yang dijelaskan Harjadi (2000) pada tanaman yang ditanam dengan jarak tanam yang terlalu rapat, maka akan terjadi persaingan dalam pengambilan unsur hara yang dibutuhkan tanaman dari dalam tanah. Syarief (2014) mengatakan bahwa unsur hara yang cukup tersedia akan dapat memacu tinggi tanaman, merangsang pertumbuhan sistem perakaran, meningkatkan hasil produksi, dan meningkatkan pertumbuhan daun sehingga dapat meningkatkan proses fotosintesis.

Tabel 3. Rata-rata bobot krop akibat pengaruh jarak tanam (gr)

\begin{tabular}{cc}
\hline Perlakuan & Bobot Krop \\
\hline $\mathrm{J}_{1}$ & $18,26 \mathrm{a}$ \\
$\mathrm{J}_{2}$ & $18,39 \mathrm{a}$ \\
$\mathrm{J}_{3}$ & $20,97 \mathrm{~b}$ \\
\hline BNT $_{0,05}$ & 0,63
\end{tabular}

Keterangan : Angka yang diikuti oleh huruf yang sama berbeda tidak nyata pada uji BNT 0,05

\section{Intensitas Serangan}

Analisis sidik ragam menunjukkan bahwa perlakuan jarak tanam tanaman bunga kol berpengaruh sangat nyata terhadap umur tanaman 4 MST akan tetapi tidak berpengaruh nyata pada umur tanaman 6 MST dan 8 MST. Ratarata jarak tanam tanaman bunga kol 4, 6, dan 8 MST disajikan pada Tabel 4.

Tabel 4. Rata-rata intensitas serangan hama (Spodopter litura) pada jarak tanam 4 MST, 6 MST,dan 8 MST.

\begin{tabular}{cccc}
\hline Perlakuan & $4 \mathrm{MST}$ & $6 \mathrm{MST}$ & $8 \mathrm{MST}$ \\
\hline $\mathrm{J}_{1}$ & $4,90 \mathrm{~b}$ & 4,15 & 3,60 \\
$\mathrm{~J}_{2}$ & $4,15 \mathrm{a}$ & 3,36 & 3,23 \\
$\mathrm{~J}_{3}$ & $3,55 \mathrm{a}$ & 2,72 & 2,90 \\
\hline BNT $_{0,05}$ & 0,12 & - & - \\
\hline \multicolumn{2}{r}{ Keterangan : Angka yang diikuti huruf yang sama pada kolom yang sama berbeda tidak nyata pada } \\
\multicolumn{4}{c}{ uji BNT 0,05 }
\end{tabular}


Hasil uji BNT pada Tabel 4 menunjukkan bahwa pada umur 4 MST dijumpai intensitas seragan tertinggi pada perlakuan $\mathrm{J}_{1}$. Hasil uji BNT menunjukkan pada perlakuan $\mathrm{J}_{1}$ berbeda nyata dengan perlakuan yang lain. Hal ini dikarenakan terjadi kompetisi antar tanaman sehingga terjadi perbedaan tinggi tanaman. Persaingan yang dilakukan organisme-organisme untuk memperebutkan kebutuhan ruang (tempat), makanan, unsur hara, air, sinar, udara, agen penyerbukan, agen dispersal, atau faktor-faktor ekologi lainnya sebagai sumber daya yang dibutuhkan oleh tiap-tiap organisme untuk hidup dan pertumbuhannya (Indriyanto, 2006).

Selain itu pengaturan populasi tanaman melalui pengaturan jarak tanam pada suatu pertanaman akan mempengaruhi keefisienan tanaman dalam memanfaatkan matahari dan persaingan tanaman dalam memanfaatkan hara dan air yang pada akhirnya mempengaruhi pertumbuhan dan produksi tanaman (Musa $d k k$, 2007). Kerapatan atau ukuran populasi tanaman sangat penting untuk memperoleh hasil yang optimal, tetapi dapat terjadi persaingan dalam hara, air, dan ruang tumbuh serta mengurangi perkembangan tinggi dan kedalaman akar tanaman (Nasir, 2010).

\section{Pengaruh Interval Penyemprotan Ekstrak Daun Kersen Pada Tanaman Bunga Kol}

\section{Tinggi Tanaman}

Analisis sidik ragam menunjukkan bahwa perlakuan faktor interval penyemprotan berpengaruh sangat nyata pada tanaman bunga kol umur 14, 21 dan 28 HST. Rata-rata tinggi tanaman kubis akibat pengaruh penyemprotan ekstrak daun kersen pada umur 14, 21 dan 28 disajikan pada Tabel 5.

Tabel 5. Rata-rata tinggi tanaman bunga kol (cm) pada umur 14, 21 dan 28 HST Penyemprotan $(\mathrm{cm})$

\begin{tabular}{cccc}
\hline \multirow{2}{*}{ Perlakuan } & \multicolumn{3}{c}{ Tinggi Tanaman $(\mathrm{cm})$} \\
\cline { 2 - 4 } & $14 \mathrm{HST}$ & $21 \mathrm{HST}$ & $28 \mathrm{HST}$ \\
\hline $\mathrm{I}_{1}$ & $19,94 \mathrm{a}$ & $22,63 \mathrm{a}$ & $25,16 \mathrm{a}$ \\
$\mathrm{I}_{2}$ & $20,47 \mathrm{~b}$ & $23,34 \mathrm{~b}$ & $24,58 \mathrm{a}$ \\
$\mathrm{I}_{3}$ & $21,61 \mathrm{c}$ & $23,26 \mathrm{a}$ & $26,92 \mathrm{~b}$ \\
\hline BNT $_{0,05}$ & 0,22 & 0,58 & 0,50
\end{tabular}

Keterangan :Angka yang diikuti pada huruf yang sama pada kolom yg sama berbeda tidak nyata pada uji BNT 0,05

Tabel 5 hasil uji BNT pada umur tanaman bunga kol 14 HST menunjukkan perlakuan $\mathrm{I}_{3}$ berbeda nyata dengan perlakuan $I_{1}$ dan $I_{2}$. Hasil uji BNT pada umur tanaman bunga kol 21 HST menunjukkan perlakuan $\mathrm{I}_{2}$ berbeda nyata dengan perlakuan yang lain. Adapun hasil uji BNT pada umur tanaman bunga kol
28 HST menunjukkan perlakuan $\mathrm{I}_{3}$ berbeda nyata dengan perlakuan $\mathrm{I}_{1}$ dan $\mathrm{I}_{2}$.

Hal ini di duga pada awal fase vegetatif pertumbuhan tanaman masih relatif terjaga hal ini dapat kita lihat dari tabel diatas menunjukkan tidak adanya perbedaan yang signifikan. Hasil penelitian juga 
menunjukan penggunaan ekstrak daun kersen menunjukkan rendahnya serangan hama ulat grayak pada tanaman kubis yang dapat memberikan hasil terbaik pada tinggi tanaman kubis.

Menurut Isnarianti $d k k$, (2013) sifat antibakteri yang aktif pada daun kersen seperti flavonoid, saponin, dan tanin menyebabkan rendahnya serangan hama ulat grayak. Sari (2013) menyatakan bahwa masing-masing zat aktif yang terdapat pada daun kersen memiliki mekanisme berbeda sebagai antibakteri.

Flavonoid

mampu

menghambat fungsi membran sitoplasma, menghambat sintesis asam nukleat, dan menghambat metabolisme energi. Saponin dapat berikatan dengan lipo polisakarida, sehingga mengakibatkan permeabilitas dinding sel meningkat. Permeabilitas yang terganggu menyebabkan keluarnya berbagai komponen penting dari sel mikroba yaitu protein, asam nukleat, nukleotida, dan lain-lain, sehingga sel bakteri akan mati. Tanin dapat menginaktivasi adhesin mikroba, enzim, dan protein transport pada membran sel.

\section{Lingkaran Krop}

Analisis sidik ragam menunjukkan bahwa perlakuan faktor interval penyemprotan berpengaruh nyata pada tanaman bunga kol. Rata-rata lingkarankrop tanaman bunga kol akibat pengaruh penyemprotan ekstrak daun kersen pada disajikan pada Tabel 6 .

Tabel 6. Rata-rata lingkaran krop (cm)

\begin{tabular}{ccc}
\hline & Perlakuan & Lingkaran Krop \\
\hline & $\mathrm{I}_{1}$ & $41,52 \mathrm{~b}$ \\
& $\mathrm{I}_{2}$ & $35,64 \mathrm{a}$ \\
& $\mathrm{I}_{3}$ & $36,91 \mathrm{a}$ \\
\hline BNT $_{0,05}$ & & 3,92
\end{tabular}

Keterangan :Angka yang diikuti oleh huruf yang sama berbeda tidak nyata pada uji BNT 0,05

Sastrodihardjo (1992)
menyatakan bahwa senyawa-
senyawa seperti flavonoid dan
terpenoid yang terdapat pada
tanaman ini dapat mempengaruhi
beberapa sistem fisiologis yang
mengatur perkembangan hama.

Senyawa lainnya yaitu saponin dapatmenurunkan aktivitas enzim protease dalam saluran pencernaan serangga, sehingga mempengaruhi proses penyerapan makanan.

Hasil uji BNT pada Tabel 6 menunjukan bahwa rata rata diameter krop pada tanamanbunga kol tertinggi dijumpai pada perlakuan $\mathrm{I}_{1}$ yang berbeda nyata dengan perlakuan yang lain. Hal ini diduga adanya pengaruh dari ekstrak daun kersen terdapatnya sifat antibakteri mengandung senyawa aktif pada daun kersen tersebut sehingga dapat mengendalikan serangan hama pada tanaman bunga kol.

\section{Bobot Krop}

Analisis sidik ragam menunjukkan bahwa perlakuan faktor interval penyemprotan berpengaruh sangat nyata pada tanaman bunga kol. Rata-rata bobot krop tanaman bunga kol akibat 
Tabel 7. Rata-rata bobot krop akibat pengaruh interval penyemprotan (gram)

\begin{tabular}{cc}
\hline Perlakuan & Bobot Krop \\
\hline $\mathrm{I}_{1}$ & $18,57 \mathrm{a}$ \\
$\mathrm{I}_{2}$ & $18,60 \mathrm{a}$ \\
$\mathrm{I}_{3}$ & $20,46 \mathrm{~b}$ \\
\hline BNT $_{0,05}$ & 0,63
\end{tabular}

Keterangan :Angka yang diikuti oleh huruf yang sama berbeda tidak nyata pada uji BNT 0,05

Hasil uji BNT pada Tabel 7 menunjukkan bahwa rata rata bobot krop pada tanaman bunga kol tertinggi dijumpai pada perlakuan $\mathrm{I}_{3}$ yang berbeda nyata dengan perlakuan yang lain. Hal ini diduga semakin lama interval penyemprotan daun kersen maka akan baik pula hasil pada bobot krop.

$$
\text { Hal ini sebagaimana }
$$

dikemukakan Sari dkk. (2013), bahwa larva yang tidak makan akan menjadi lemah, mobilitasnya berkurang karena terdapat senyawa alkaloid dan flavonoid. Alkaloid menghambat reptor perasa pada mulut larva. Akibatnya larva gagal mendapatkan stimulus rasa sehingga tidak mampu mengenali makanannya, mengakibatkan larva mati kelaparan. Sehingga dapat meningkatkan jumlah bobot krop pada tanaman bunga kol.

\section{Intensitas Serangan}

Analisis sidik ragam menunjukkan bahwa perlakuan interval penyemprotan ekstrak daun kersen berpengaruh sangat nyata pada 4, 6 dan 8 MST. Rata-rata interval penyemprotan 4,6 dan 8 MST disajikan pada Tabel 8.

Tabel 8. Rata-rata intensitas serangan hama (Spodopter litura) pada Umur 4, 6 dan 8 MST

\begin{tabular}{cccc}
\hline Perlakuan & 4 MST & 6 MST & 8 MST \\
\hline $\mathrm{I}_{1}$ & $4,55 \mathrm{~b}$ & $3,91 \mathrm{~b}$ & $3,60 \mathrm{~b}$ \\
$\mathrm{I}_{2}$ & $4,44 \mathrm{a}$ & $3,12 \mathrm{a}$ & $3,23 \mathrm{a}$ \\
$\mathrm{I}_{3}$ & $3,55 \mathrm{a}$ & $2,72 \mathrm{a}$ & $2,90 \mathrm{a}$ \\
\hline BNT $_{0,05}$ & 0,12 & 0,32 & 0,26 \\
\hline
\end{tabular}

Keterangan : Angka yang diikuti pada huruf yang sama pada kolom yang sama berbeda tidak nyata pada uji BNT 0,05

Hasil uji BNT menunjukkan pada umur 4, 6 dan 8 MST, perlakuan $\mathrm{I}_{1}$ berbeda nyata dengan perlakuan yang lain. Diduga pengendalian pada fase vegetatif masih sangat rendah sehingga intensitas serangan hama lebih tinggi. Konsentrasi penyemprotan sangat berpengaruh terhadap keberhasilan pengendalian hama dan produksi kubis (Prijono dan Triwidodo, 1993).

Diduga efektifitas pestisida nabati kurang efektif apabila terkena sinar matahari. Soehardjan (1994); Nakamura (1993), menyatakan bahwa pestisida nabati kurang efektif dan mudah terdegredasi jika terkena sinar matahari dan toksisitasnya menurun. 
Pengaruh Interaksi Interval Penyemprotan Ekstrak Daun Kersen dan Faktor Jarak Tanam pada Tanaman Bunga Kol terhadap Hama (Spodoptera litura, F)

Hasil analisis sidik ragam menunjukkan bahwa pengaruh interaksi antara perlakuan interval penyemprotan dan jarak tanam berpengaruh sangat nyata terhadap intensitas serangan umur 4 MST dan berpengaruh nyata terhadap tinggi tanaman bunga kol pada umur 14 HST. Rata- rata tinggi tanaman pada umur 14 HST dan intensitas serangan umur 4 MST akibat pengaruh interval penyemprotan dan jarak tanam disajikan pada Tabel 9.

Tabel 9. Rata-rata tinggi tanaman pada umur 14 HST dan intensitas serangan 4 MST

\begin{tabular}{ccc} 
MST & Tinggi Tanaman & $\begin{array}{c}\text { Intensitas seranagan } \\
\text { Perlakuan }\end{array}$ \\
\hline $\mathrm{I}_{1} \mathrm{~J}_{1}$ & $18,90 \mathrm{a}$ & $5,99 \mathrm{~b}$ \\
$\mathrm{I}_{1} \mathrm{~J}_{2}$ & $20,87 \mathrm{c}$ & $3,96 \mathrm{a}$ \\
$\mathrm{I}_{1} \mathrm{~J}_{3}$ & $20,06 \mathrm{~b}$ & $3,71 \mathrm{a}$ \\
$\mathrm{I}_{2} \mathrm{~J}_{1}$ & $19,49 \mathrm{ab}$ & $4,89 \mathrm{a}$ \\
$\mathrm{I}_{2} \mathrm{~J}_{2}$ & $20,78 \mathrm{c}$ & $4,38 \mathrm{a}$ \\
$\mathrm{I}_{2 \mathrm{~J} 3}$ & $21,13 \mathrm{c}$ & $4,04 \mathrm{a}$ \\
$\mathrm{I}_{3} \mathrm{~J}_{1}$ & $19,98 \mathrm{~b}$ & $3,83 \mathrm{a}$ \\
$\mathrm{I}_{3} \mathrm{~J}_{2}$ & $21,29 \mathrm{c}$ & $4,10 \mathrm{a}$ \\
$\mathrm{I}_{3} \mathrm{~J}_{3}$ & $23,58 \mathrm{~d}$ & $2,73 \mathrm{a}$ \\
\hline $\mathrm{BNT}_{0,05}$ & 0,65 & 0,37
\end{tabular}

Keterangan : Angka yang diikuti a huruf yang sama pada kolom yang sama berbeda tidak nyata pada uji BNT 0,05 
Tabel 9 menunjukan bahwa tanaman bunga kol tertinggi pada umur 14 HST dijumpai pada pelakuan $\mathrm{I}_{3} \mathrm{~J}_{3}$ sedangkan yang terendah dijumpai pada perlakuan $\mathrm{I}_{1} \mathrm{~J}_{1}$. Hasil uji BNT menunjukkan bahwa tanaman bunga kol pada perlakuan $\mathrm{I}_{3} \mathrm{~J}_{3}$ berbeda nyata dengan perlakuan lainnya. Pengaruh interval penyemprotran ekstrak daun kersen berpengaruh untuk mengendalikan hama Spodoptera litura. Hal ini disebabkan karena adanya kandungan senyawa aktif alkaloid, saponin, flavonoid yang dapat menghambat pencernaan hama dan menolak hama untuk melakukan proses metabolisme.

Hal ini dimungkinkan karena adanya interval penyemprotan atau waktu sehingga dapat menunjukkan bahwa hasil terbaik tanaman bunga kol akibat faktor jarak tanam tertinggi ditemui pada perlakuan $\mathrm{J}_{3}(60 \times 60)$ karena tidak terjadinya perebutan unsur hara dan tanaman dapat tumbuh dengan optimal dengan adanya interval penyemprotan ekstrak daun kersen maka tanaman dapat dikendalikan dari serangan hama Spodoptera litura F, juga dapat meningkatkan ketersediaan hara,hasil tanaman dan mengurangi resiko kegagalan panen.

Pengaturan jarak tanam sangat berpengaruh terhadap pertumbuhan dan hasil tanaman bunga kol terutama pada masa pembentukan krop, yaitu sangat bervariasi antara bulat telur, gepeng, dan berbentuk kerucut. Dengan demikian jarak tanam ditunjukkan untuk memanfaatkan cahaya secara efektif dan penyebaran unsur hara secara merata (Rukmana, 2005).

Hasil uji BNT menunjukkan bahwa intensitas serangan $\mathrm{I}_{1} \mathrm{~J}_{1}$ berbeda nyata dengan semua perlakuan. Dalam hal ini dapat kita lihat bahwa penggunaan interval penyemprotan ekstrak daun kersen $3 \mathrm{x}$ penyemprotan dalam 1 minggu efektif dalam menurunkan intensitas serangan hama ulat grayak, dikarena terdapat senyawa aktif seperti alkaloid, flavonoid, saponin dan tanin yang dapat mengendalikan hama ulat grayak pada areal tanaman kubis.

Shahabuddin dan Anshary (2010) menyatakan bahwa semakin besarnya kadar bahan aktif yang bersifat toksik dalam formula, juga diduga karena kurangnya nutrisi yang dikonsumsi oleh larva akibat adanya senyawa anti makan dalam formula yang diperlakukan sehingga meningkatkan daya racun terhadap serangga uji. Penggunaan jarak tanam $60 \times 60 \mathrm{~cm}$ efektif dapat menekan intensitas serangan hama ulat grayak dibandingkan jarak tanam yang lebih rapat seperti dikemukakan oleh Hill (2003) bahwa jarak tanam dapat menambah atau meningkatkan efektivitas musuh alami, meningkatkan vigoritas tanaman, mengganggu perilaku hama dalam mencari makanan dan peletakan telur serta mengubah kerentanan tanaman terhadap hama. Kerentanan tanaman terhadap serangan hama dan penyakit tersebut juga dipicu oleh adanya peningkatan kandungan nutrisi pada daun.

\section{KESIMPULAN DAN SARAN \\ Kesimpulan}

1. Pengaruh jarak tanam bunga kol berpengaruh sangat nyata terhadap tinggi tanaman umur 14 HST, bobot krop, dan intensitas serangan 4 MST berpengaruh nyata pada tinggi tanaman umur 21 dan 28 HST, dan lingkaran krop. Jarak tanam terbaik 
dijumpai pada perlakuan $\mathrm{J}_{3}(60 \mathrm{x}$ 60).

2. Interval penyemprotan ekstrak daun kersen berpengaruh sangat nyata terhadap tinggi tanaman umur 14, 21, dan 28 HST, bobot krop dan intesitas serangan 4 MST, 6 MST dan 8 MST berpengaruh nyata terhadap lingkaran krop. Interval penyemprotan terbaik dijumpai pada perlakuan $\mathrm{I}_{3}$ (8 MST).

3. Interaksi interval penyemprotan dan pengaruh jarak tanam berpengaruh sangat nyata pada pengamatan intensitas serangan umur 4 MST tetapi berpengaruh tidak nyata terhadap semua parameter lainnya. Kombinasi perlakuan terbaik dijumpai pada pengamatan tinggi tanaman yaitu pada perlakuan $\mathrm{I}_{3} \mathrm{~J}_{3}(8$ MST dan $60 \quad x \quad 60)$ dan berpengaruh nyata terhadap tinggi tanaman.

\section{Saran}

Untuk mengendalikan hama ulat (Spodoptera litura F) pada tanaman bunga kol disarankan menggunakan interval penyemprotan ekstrak daun kersen dengan penyemprotan tiga kali penyemprotan dalam satu minggu dan disarankan menggunakan jarak tanam $60 \mathrm{x} \quad 60 \mathrm{~cm}$ untuk mendapatkan pertumbuhan dan hasil yang optimal.

\section{DAFTAR PUSTAKA}

Ashari.1995. Holtikultura Aspek Budidaya. Universitas Indonesia. Jakarta.

Hill, S.B. 2003. Cultural methods of pest, primarily insect,control. Ecological Agriculture Projects. McGill
University. Tanggal akses 5

Pebruari2017

dari:http://eap.mcgill

Indriyanto. 2006. Ekologi Hutan. Bumi Aksara. Jakarta.

Suprapto. J. 1992. Teknik Sampling Untuk Survey dan Eksperimen, Rinika Cipta. Jakarta.

Hanafiah, K.A. 2010. Rancangan Percobaan Teori dan Aplikasi Edisi Ketiga. Universitas Sriwijaya. Palembang.

Harjadi, S. 2000. Pengantar Agronomi. Gramedia. Jakarta.

Isnarianti, R., Wahyudi,I., Puspita, R. 2013. Muntingia Calabura, L Leaves Extract Inhibits Gluco syltrans ferase Actifity of Streptococcus mutans. Journal of Dentistry Indonesia. 20(3): 59-63

Musa, Y., Nasarudin., Kuruseng, M.A. 2007. Evaluasi produktivitas jagung melalui pengelolaan populasi tanaman, pengolahan tanah, dan dosis pemupukan. Jurnal Agrisistem 1: 21- 33.

Nakamura, K. 1993. Pesticides Effect. Kanazawa Univesrsity Press. Japan.

Nasir, A. 2010. Pengaruh Jarak Tanam terhadap Pertumbuhan dan Perkembangan

Tanaman.(http://ahmadnasir .blo gspot.com/jaraktanam.htm.). Diakses pada tanggal 18 April 2019. 100-102

Prawitasari, T. 2003. Siknal Fisiologi pada Transisi ke Pertumbuhan

Perkembangan Reproduktif. P2KSDM. Bogor. 
Prijono, D., Triwidodo, H. 1993. Pemanfaatan Insektisida Nabati di Tingkat Petani dalam Prosiding Seminar Hasil Penelitian dalam Rangka Pemanfaatan Pestisida Nabati. Bogor. Hlm 76-85.

Rukmana H. 2005. Bertanam Kubis. Kanisius, Yogyakarta.

Sari, M., Lubis, L., Pangestiningsih, Y. 2013.Uji Efektivitas Beberapa Insektisida Nabati untuk Mengendalikan Ulat Grayak (Spodoptera litura F.) (Lepidoptera : Noctuidae) di Laboratorium. Program Studi Agroteknologi. Fakultas Pertanian, Universitas Sumatera Utara. Medan. Jurnal Online Agroteknologi 1(3).

Sastrodihardjo, S., Adianto, Yusuf M., 1992. The Impact of Several Insecticides on Ground and Water Communities. Proceedings South East Asian Workshop on Pestiside Management. (7): 117-125 .

Setyatim S.1983. Pengantar Agronomi. Gramedia. Jakarta.

Shahabuddin., Anshary, A. 2010. Uji Aktivitas Insektisida Ekstrak Daun Serai terhadap Ulat Daun Kubis (Plutella xylostella, L.). Jurnal Agroland 17(3): 178-183.

Soehardjan, M. 1994. Konsepsi dan strategi penelitiandan pengembangan pestisida nabati. Prosiding Seminar Hasil Penelitian dalam Rangka Pemanfaatan Pestisida Nabati. 1-2
Desember 1993. Balittro. hlm. 11-18

Syarief, M. 2014. Pengaruh teknik budidaya kubis terhadap diversitas arthropoda dan intensitas serangan Plutella xylostella l. (Lepidoptera: Plutellidae). ISSN 14115549.

Untung, K. 2013. Pengantar Pengelolaan Hama Terpadu. Universitas Gajah Mada. Yogyakarta.

Widodo, S. 2013. Hama dan Pengendalian Jarak Kepyar. Badan Penyuluhan dan Pengembangan Sumber Daya Manusia Pertanian. Jakarta.

Zakaria Z, A., Mohd N, A., Hazalim N., et al . 2007. Antinociceptive, antiinflammatory and antipyretic effects of Muntingia calabura aqueous extract in animal models. J. Nat. Med. 61:443-8. 